\title{
Minerals and Heavy Metal Composition in Seaweeds of the Eastern Coast, Northern Bay of Bengal, Bangladesh
}

\author{
Kamrun Nahar Chowdhury ${ }^{1}$, Md. Kawser Ahmed ${ }^{1,2}$, Kazi Turjaun Akhter ${ }^{3}$, Seema Rani ${ }^{2}$ and \\ Makidul Islam Khan ${ }^{2}$
}

\author{
${ }^{1}$ Department of Oceanography, University of Dhaka, Dhaka 1000, Bangladesh \\ ${ }^{2}$ International Centre for Ocean Governance (ICOG), University of Dhaka, Dhaka 1000, Bangladesh \\ ${ }^{3}$ Institute of Nutrition and Food Science, University of Dhaka, Dhaka 1000, Bangladesh
}

Manuscript received: 25 August 2021; accepted for publication: 27 November 2021

\begin{abstract}
This study aimed to analyze minerals $(\mathrm{Ca}, \mathrm{Mg}, \mathrm{Fe}, \mathrm{Zn}, \mathrm{Mn}$ and $\mathrm{Cu})$ and heavy metals $(\mathrm{Pb}$ and $\mathrm{Cd})$ content of seaweeds collected from coastal waters of Bangladesh using Atomic Absorption Spectrophotometer (AAS). Eight wild species in three phyla viz. Rhodophyta (Hypnea sp.), Chlorophyta (Enteromorpha sp.), and Phaeophyta (Sargassum sp., Hydroclathrus clathratus, Padina pavonica, Colpomenia sinuosa, Petalonia fascia and Dictyota ciliolata) and one cultured Rhodophyta species viz. Hypnea sp. were collected from St. Martin's Island and Cox's Bazar, respectively. Results showed minerals and heavy metals concentrations were varied from species to species. Ca concentration was the highest in Phaeophyta $(18565 \mathrm{mg} / \mathrm{kg}-\mathrm{dw})$ and it was 19 times higher than the value reported in Chlorophyta (950 mg/kg-dw). In contrast, Fe, Zn and Mn were the highest in Rhodophyta. This is because different groups of seaweeds affinity to absorb minerals depend on environmental parameters for example salinity, $\mathrm{pH}$ and light intensity, mineral accessibility in sea water and interactions between elements, growth and metabolic factors, etc. Ca content was the highest in C. sinuosa $(30890 \mathrm{mg} / \mathrm{kg}-\mathrm{dw})$, whereas, it was the lowest in cultured Hypnea sp. (120 $\mathrm{mg} / \mathrm{kg}-\mathrm{dw})$. P.pavonica showed the highest concentrations of Fe $(15030 \mathrm{mg} / \mathrm{kg}-\mathrm{dw}), \mathrm{Zn}(33.46 \mathrm{mg} / \mathrm{kg}-\mathrm{dw})$ and $\mathrm{Mn}$ (443.79 mg/kg-dw). Mineral contents of cultured seaweeds were comparatively lower than the wild species. Results showed mineral concentrations in all seaweeds were relatively greater than heavy metals. However, wild Hypnea sp. contained slightly 2 times higher Cd $(2.11 \mathrm{mg} / \mathrm{kg}-\mathrm{dw})$ than the cultured Hypnea sp. $(0.98 \mathrm{mg} / \mathrm{kg}-\mathrm{dw})$ due to higher level of anthropogenic source of pollution in St. Martin's Island. Heavy metal contamination in seaweeds might raise health concerns among the consumers. Findings of this study might help to unleash minerals and heavy metals compositions of the studied seaweeds of Bangladesh. Policy makers can formulate and establish health safety guidelines for safe consumption of seaweeds.
\end{abstract}

Keywords: Macroalgae, Toxic metals, Health risk, Functional food, Bangladesh

\section{INTRODUCTION}

Seaweeds or marine macro-algae are rich in natural vitamins, fibres, lipids, minerals and proteins and that is why direct consumption of seaweeds is widely growing because of its high nutritional values and health benefits (Rupérez, 2002; Chen et al., 2018). Seaweeds contain higher level of minerals in their cell walls than terrestrial plants (Rupérez, 2002) and in some cases, the percentage of minerals would be up to 40\% (Kumar et al., 2011; Nwosu et al., 2011). Seaweeds also contained significant extent of bioactive substance that showed antifungal, antibacterial, and antiviral properties (Kumar et al.,

Corresponding author: Dr. Md. Kawser Ahmed

Email: kawser@du.ac.bd

DOI: https://doi.org/10.3329/dujees.v10i2.57514
2008). Seaweeds are considered as nutritional or functional food for the coastal people. Overwhelming majority of coastal people of Bangladesh (13.8\% of the total population) live in poverty line (World Bank, 2018) who cannot afford to fulfill the daily requirement of nutritional foods. In this case, to meet the demand of nutrient rich foods including proteins or minerals, the coastal poor people can get highly nutritive seaweeds at a low-cost which are naturally grown in intertidal, tidal and subtidal regions of coastal waters (Khandaker et al., 2021).

The coastal waters of Bangladesh are very suitable for growing diverse number of natural seaweeds. In total 193 (Sarkar et al., 2016) or 244 (Uddin, 2019) seaweed species including 17 (Rani et al., 2020) or 19 (Sarkar et al., 2016) commercially important species are found in coastal waters. Among them, a total of 140 to 155 species are naturally grown in coastal waters of St. Martin's Island and Cox's 
Bazar. However, till now scientists of Bangladesh Fisheries Research Institute (BFRI) have confirmed that 116 species are present in coastal regions of Bangladesh (DoF, 2019). There are 14 potential candidates of culturable species where only five species viz. Gracilaria tenuistipitata, Hypnea musciformis, Ulva intestinalis and $U$. lactuca (Hossain et al., 2021) and Enteromorpha sp. (Feed the Future, 2021) are farmed in Cox's Bazar district, Bangladesh but in small amount.

Coastal and estuarine waters of Bangladesh particularly east coast of Cox's Bazar and St. Martin's Island are severely polluted due to anthropogenic activities such as dumping from chemical industries, surface runoff and agricultural activities, wastewater discharging, mining, etc. (Rani et al., 2021). As a consequence, health anxiety has been elevated regarding potential contamination of heavy metals in seaweeds since seaweeds could accumulate elevated contents of heavy metals in their body from the seawater (Chen et al., 2018). This is because some metals like $\mathrm{Cd}, \mathrm{Pb}$ and $\mathrm{Hg}$ can be noxious at a minute concentration and biologically indispensable metals could result in lethal effects at higher concentrations.

Globally several studies were directed to analyze minerals and heavy metals contents in seaweeds (e.g., Rupérez, 2002; Rubio et al., 2017; Chen et al., 2018; Yoganandham et al., 2019; Khandaker et al., 2021; etc.). Despite having many naturally available seaweeds in coastal waters of Bangladesh, there has scarce studies (e.g., Khan et al., 2016) on estimating mineral concentrations from them. Therefore, the use of this nutritious seaweed as a functional food is still underutilized as people are not yet aware of the details nutritional value of each seaweed. Types and contents of minerals in seaweeds are varied depending on diverse geographical origins, methods of mineralization, wave exposures, tidal fluctuations, pollution levels and seasonal differences, etc. (Carlson and Erlandsson, 1991; Topcuoğlu et al., 2003; Żbikowski et al., 2006; Astorga-España et al., 2015). At the same time, the potential health risk of seaweeds consumption is very obligatory to understand. However, there has no study to analyze potential heavy metals contamination in seaweeds from coastal waters of Bangladesh for health safety issues. That is why, the present study aimed to analyze minerals and heavy metals concentrations in seaweeds collected from coastal waters of the St. Martin's Island and
Cox's Bazar, Bangladesh, northern Bay of Bengal. The findings of this study might help to understand the minerals and heavy metals compositions of the studied seaweeds of Bangladesh. Based on the findings the policy makers can formulate and establish health management guidelines for safe consumption of seaweeds.

\section{MATERIALS AND METHODS}

\section{Study sites}

In this study, a total of eight (8) wild seaweed species in three phyla viz. Rhodophyta or red seaweed (Hypnea sp.), Chlorophyta or green seaweed (Enteromorpha sp.), and Phaeophyta or brown seaweed (Sargassum sp., Hydroclathrus clathratus, Padina pavonica, Colpomenia sinuosa, Petalonia fascia and Dictyota ciliolata), and only one cultured red seaweed species of Hypnea sp. were collected from the western coast of St. Martin's Island $\left(20^{\circ} 37^{\prime}\right.$ $\mathrm{N}$ and $92^{\circ} 19^{\prime} \mathrm{E}$ ) and Nunairchhara, Cox's Bazar $\left(21^{\circ} 28^{\prime} \mathrm{N}\right.$ and $\left.91^{\circ} 57^{\prime} \mathrm{E}\right)$ of the south-eastern part of Bangladesh, northern Bay of Bengal, respectively. All seaweed samples were carefully washed in running seawater and rinsed with tap water to eliminate all unwanted materials such as salt and foreign particles e.g., epiphytes, shells, sand, debris, etc. Finally, samples were preserved into plastic jars using $4-5 \%$ of alcohol.

\section{Sample preparation}

All seaweed samples were gently rinsed with deionized water at the laboratory of Dhaka University and air-dried for 3 days. Later samples were ovendried at $105^{\circ} \mathrm{C}$ for overnight and then the dried samples were grinded into powder using a mortar and pestle. All powdered seaweed samples were kept in the desiccators at room temperature until chemical analyses were done.

\section{Biochemical analyses to estimate minerals and heavy metals}

\section{Microwave digestion}

For the microwave digestion less than $0.50 \mathrm{~g}$ of powdered seaweed samples were taken into a clean and dry microwave Teflon vessel. Later, added $8 \mathrm{ml}$ of $\mathrm{HNO}_{3}$ to the samples. A seal forming device was applied to enlarge the lip-seals on all vessel's caps. The vessels were stored in a bomb jacket with attached lids and kept in the microwave to digest the 
samples at $200^{\circ} \mathrm{C}$ for 10 minutes (FSSAI, 2015). Then the vessels were transferred in a fume hood from the microwave. The caps of all vessels were carefully unbolted to remove nitrogen oxides. Finally, the digested samples were moved into $50 \mathrm{ml}$ volumetric flasks through filtration and diluted with distilled water. Then clear solutions were moved into falcon tube for Atomic Absorption Spectrophotometer (AAS) (AAnalyst 200, Perkin-Elmer and USA) analysis. Blank was prepared in similar process without adding any seaweed sample. Appropriate dilutions containing $0.4 \%$ lanthanum $(\mathrm{w} / \mathrm{v})$ to overcome ionic interferences were used to determine calcium $(\mathrm{Ca})$ and magnesium $(\mathrm{Mg})$.

\section{Standard wave length, detection limit and curve for minerals and heavy metals}

The contents of six minerals viz. $\mathrm{Ca}, \mathrm{Mg}, \mathrm{Fe}, \mathrm{Zn}$, $\mathrm{Mn}$ and $\mathrm{Cu}$, and two heavy metals viz. $\mathrm{Pb}$ and $\mathrm{Cd}$ were determined by flame AAS after appropriate microwave digestion of the samples. Hollow cathode lamps of each element were used to analyze the wave length of all minerals and heavy metals (Table 1). The device was calibrated with standard solutions.

Table 1: List of Wave Length and Detection Limit of Minerals and Heavy Metals

\begin{tabular}{llll}
\hline & Hollow cathode lamps & Wave length $(\mathrm{nm})$ & Minimum detection limit $(\mathrm{mg} / \mathrm{kg})$ \\
\hline $\mathrm{Minerals}$ & & & \\
\hline $\mathrm{Ca}$ & Calcium hollow cathode lamps & 422.7 & 0.06 \\
\hline $\mathrm{Mg}$ & Magnesium hollow cathode lamps & 279.5 & 0.01 \\
\hline $\mathrm{Fe}$ & Iron hollow cathode lamps & 248.3 & 0.04 \\
\hline $\mathrm{Zn}$ & Zinc hollow cathode lamps & 213.9 & 0.01 \\
\hline $\mathrm{Mn}$ & Manganese hollow cathode lamps & 285.2 & 0.01 \\
\hline $\mathrm{Cu}$ & Copper hollow cathode lamps & 324.8 & 0.03 \\
\hline $\mathrm{Heavy}$ metals & & & 0.18 \\
\hline $\mathrm{Pb}$ & Lead hollow cathode lamps & 283.3 & 0.01 \\
\hline $\mathrm{Cd}$ & Cadmium hollow cathode lamps & 228.8 & \\
\hline
\end{tabular}

\section{Quality Assurance and Quality Control}

In this study, all laboratory instruments including materials for sample preparation and analytical procedures were acid-cleaned to avoid contamination risk. All analytical devices were carefully calibrated before doing any analysis to certify that it was functioning properly within the accepted ranges. Moreover, the accuracy and precision of the minerals and heavy metal concentrations of seaweeds were evaluated by quality assurance and quality control (QA/QC) procedures, which also implied for the analysis of blank and samples (USEPA, 1995). The accuracy of minerals and heavy metals concentration in seaweed samples was verified by standard samples analysis. The calibration curves with coefficient values $\left(\mathrm{r}^{2}\right)>0.998$ were used to calculate minerals and heavy metals concentrations of seaweeds (Table 2) and the estimated concentrations were expressed as $\mathrm{mg} / \mathrm{kg}$, dry weight (dw) basis. Blank samples were also digested following the similar procedures that were used to measure minerals and heavy metal contents in seaweed samples. The minimum detection limit for $\mathrm{Ca}, \mathrm{Mg}, \mathrm{Fe}, \mathrm{Zn}, \mathrm{Mn}, \mathrm{Cu}, \mathrm{Pb}$ and $\mathrm{Cd}$ were $0.06,0.01,0.04,0.01,0.01,0.03,0.18$ and 0.01 $\mathrm{mg} / \mathrm{kg}-\mathrm{dw}$, respectively (Table 1 ).

Table 2: Standard Solution for Calibration Curve of Minerals and Heavy Metals

\begin{tabular}{lll}
\hline & $\begin{array}{l}\text { Amount of standard } \\
\text { solution }(\mathrm{mg} / \mathrm{L})\end{array}$ & $\begin{array}{l}\text { Correlation } \\
\text { coefficient }\end{array}$ \\
\hline Minerals & & \\
\hline $\mathrm{Ca}$ & $1.0,2.0,3.0,4.0,5.0$ & 0.999024 \\
\hline $\mathrm{Mg}$ & $0.2,0.4,0.6,0.8,1.0$ & 0.998744 \\
\hline $\mathrm{Fe}$ & $0.5,1.0,1.5,2.0,3.0$ & 0.999811 \\
\hline $\mathrm{Zn}$ & $0.2,0.4,0.6,0.8,1.0$ & 0.998461 \\
\hline $\mathrm{Mn}$ & $0.2,0.4,0.6,0.8,1.0$ & 0.999641 \\
\hline $\mathrm{Cu}$ & $0.2,0.4,0.6,0.8,1.0$ & 0.999180 \\
\hline $\mathrm{Heavy}$ metals & \\
\hline $\mathrm{Pb}$ & $0.5,1.0,2.0,3.0,4.0$ & 0.999537 \\
\hline $\mathrm{Cd}$ & $0.2,0.4,0.5,0.6,1.0$ & 0.998462 \\
\hline
\end{tabular}

\section{Statistical analysis}

The amount of minerals $(\mathrm{Ca}, \mathrm{Mg}, \mathrm{Fe}, \mathrm{Zn}, \mathrm{Mn}$ and $\mathrm{Cu})$ and heavy metals $(\mathrm{Pb}$ and $\mathrm{Cd})$ in seaweeds were 
calculated from the readings of AAS at specific wave length using specific hollow cathode lamp. In this study, the mineral and heavy metal concentration of cultured seaweed species was excluded while estimating the differences of mineral concentrations in wild seaweed algal groups. Descriptive statistics were used to analyze the data in Microsoft Excel (version-2013). Data were presented in tabular and graphical forms.

\section{RESULTS AND DISCUSSION}

\section{Mineral and heavy metal concentrations in seaweeds}

This study showed mineral concentrations in different seaweed species were varied from species to species. The highest concertation of $\mathrm{Ca}(30890 \mathrm{mg} / \mathrm{kg}$ $\mathrm{dw})$ was found in $C$. sinuosa,whereas, the lowest concentration was recorded in cultured Hypnea sp. (120 $\mathrm{mg} / \mathrm{kg}-\mathrm{dw}$ ) (Table 3). The amount of estimated $\mathrm{Ca}$ concentration was also very low in Enteromorpha sp. of green seaweeds compared with $C$. sinuosa. The reported $\mathrm{Ca}$ concentrations of $C$. sinuosa (52269 $\mathrm{mg} / \mathrm{kg}-\mathrm{dw})$ and $P$. pavonica $(31878 \mathrm{mg} / \mathrm{kg}-\mathrm{dw})$ collected from Qheshm Island in the south of Iran (Tabarsa et al., 2012) were comparatively higher than the results of the present study. The differences might be occurred due to environmental changes such as geographical location, tidal fluctuations, minerals in seawater availability and wave exposure (AstorgaEspaña et al., 2015). Khan et al. (2016) reported that the concentration of Ca was $1021 \mathrm{mg} / \mathrm{kg}-\mathrm{dw}$ in Hypnea sp. collected from coastal water of eastern St. Martin's Island, Bangladesh that was lower than the estimated Ca concentration in wild Hypnea sp. (11170 mg/kg-dw) of this study. However, Khan et al. (2016) showed a slightly higher $\mathrm{Ca}$ concentration in Enteromorpha sp. than the present study. This could be happened due to changes of mineralization methods, wave exposures and tidal fluctuations.

Among all seaweeds, $\mathrm{Mg}$ concentration was varied from $2160 \mathrm{mg} / \mathrm{kg}$-dw to $17540 \mathrm{mg} / \mathrm{kg}$-dw (Table 3). The maximum concentration of $\mathrm{Mg}$ was recorded in green seaweed Enteromorpha sp. (17540 mg/kg-dw) followed by brown seaweeds $D$. ciliolata $(10810 \mathrm{mg} / \mathrm{kg}-\mathrm{dw})$ and $P$. pavonica $(10780 \mathrm{mg} / \mathrm{kg}-\mathrm{dw})$, whereas, the lowest concentration was recorded in cultured red seaweed Hypnea sp. (2160 mg/kg-dw). P. pavonica also exhibited the maximum concentrations of $\mathrm{Fe}(15030 \mathrm{mg} / \mathrm{kg}-\mathrm{dw})$, $\mathrm{Zn}$ (33.46 mg/kg-dw) and $\mathrm{Mn}$ (443.79 mg/kg-dw). Tabarsa et al. (2012) reported the concentration of $\mathrm{Fe}$ and $\mathrm{Mn}$ in $P$. pavonica were $2498.7 \mathrm{mg} / \mathrm{kg}$ - $\mathrm{dw}$ and $103.3 \mathrm{mg} / \mathrm{kg}-\mathrm{dw}$ respectively that were not in line with the present study. Khan et al. (2016) showed the reported concentration of Fe (125 mg/kg-dw) in wild Hypnea sp. was very low than the estimated concentration of $\mathrm{Fe}$ $(11670 \mathrm{mg} / \mathrm{kg}-\mathrm{dw})$ in wild Hypnea sp. in this study. The concentration of $\mathrm{Zn}$ in different seaweeds was varied from $10.60-33.46 \mathrm{mg} / \mathrm{kg}-\mathrm{dw}$ in this study. Results showed that all studied seaweeds contained the lowest amount of $\mathrm{Cu}$ than rest of the minerals and the range of $\mathrm{Cu}$ concentrations varied from 3.13-16.48 mg/kg-dw (Table 3) that was comparatively lower than the differences in other mineral concentrations in different seaweeds. This is because seaweeds usually comprise very small amount of $\mathrm{Cu}$ contents compared to other foods (Muñoz and Díaz, 2020).

Table 3: Concentration (mg/kg-dw) of Minerals and Heavy Metals Estimated from Wild (otherwise specified) Seaweed Species Collected from St. Martin Island

\begin{tabular}{|c|c|c|c|c|c|c|c|c|c|}
\hline \multirow{3}{*}{ Phyla } & \multirow{3}{*}{ Species name } & \multicolumn{8}{|c|}{ Concentration (mg/kg-dw) } \\
\hline & & \multicolumn{6}{|c|}{ Minerals } & \multicolumn{2}{|c|}{ Heavy metals } \\
\hline & & $\mathrm{Ca}$ & $\mathrm{Mg}$ & $\mathrm{Fe}$ & $\mathrm{Zn}$ & $\mathrm{Mn}$ & $\mathrm{Cu}$ & $\mathrm{Pb}$ & $\mathrm{Cd}$ \\
\hline \multirow{2}{*}{$\begin{array}{l}\text { Red } \\
\text { seaweed }\end{array}$} & Hypnea sp. $^{\mathrm{a}}$ & 120 & 2160 & 2640 & 10.60 & 143.38 & 3.13 & $\mathrm{BDL}^{\mathrm{b}}$ & 0.98 \\
\hline & Hypnea sp. & 11170 & 6200 & 11670 & 25.87 & 304.14 & 7.30 & 9.33 & 2.11 \\
\hline $\begin{array}{l}\text { Green } \\
\text { seaweed }\end{array}$ & Enteromorpha sp. & 950 & 17540 & 5560 & 15.13 & 209.78 & 8.09 & 9.29 & 2.56 \\
\hline \multirow{6}{*}{$\begin{array}{l}\text { Brown } \\
\text { seaweed }\end{array}$} & Sargassum sp. & 13000 & 4100 & 1140 & 11.36 & 33.40 & 5.75 & $\mathrm{BDL}^{\mathrm{b}}$ & 2.87 \\
\hline & $\begin{array}{l}\text { Hydroclathrus } \\
\text { clathratus }\end{array}$ & 15680 & 3090 & 9350 & 16.72 & 197.16 & 10.00 & 8.00 & 1.11 \\
\hline & Padina pavonica & 27620 & 10740 & 15030 & 33.46 & 443.79 & 12.91 & 20.55 & 3.55 \\
\hline & Colpomenia sinousa & 30890 & 4970 & 10120 & 24.84 & 309.49 & 16.48 & 16.99 & 2.05 \\
\hline & Petalonia fascia & 10630 & 5430 & 5710 & 22.85 & 127.38 & 11.34 & 6.00 & 2.22 \\
\hline & Dictyota ciliolata & 13570 & 10810 & 5110 & 11.09 & 136.13 & 7.01 & 6.13 & 1.52 \\
\hline
\end{tabular}

${ }^{\mathrm{a} C u l t u r e d ~ s e a w e e d ~ s p e c i e s ~ c o l l e c t e d ~ f r o m ~ C o x ' s ~ B a z a r, ~}{ }^{\mathrm{b}}$ Below detection limit 
The mineral concentrations in cultured seaweed species were comparatively much lower and, in case of $\mathrm{Ca}, \mathrm{Mg}$ and $\mathrm{Zn}$, it was the lowest than all wild seaweed species. Comparing wild Hypnea sp., all minerals' concentrations in cultured Hypnea sp. was very low. This might be because of culturing Hypnea sp. crowdedly in one place (e.g., rope method) than the wild counterparts. On other hand, wild Hypnea sp. showed higher mineral contents because of growing separately in wide places. However, the harvests from the wild are limited.

This study reported wild Hypnea sp. contained higher level of heavy metals than the cultured Hypnea sp. (Table 3). Results showed the concentration of $\mathrm{Pb}$ was $9.33 \mathrm{mg} / \mathrm{kg}-\mathrm{dw}$ in wild Hypnea $\mathrm{sp}$., whereas, $\mathrm{Pb}$ was not detected in cultured species. Wild Hypnea sp. contained slightly 2 times higher $\mathrm{Cd}$ concentration $(2.11 \mathrm{mg} / \mathrm{kg}-\mathrm{dw})$ than the cultured Hypnea sp. (0.98 $\mathrm{mg} / \mathrm{kg}-\mathrm{dw}$ ). This study concluded heavy/toxic metals contaminations in seaweeds were comparatively higher in wild species (St. Martin's Island) than farmed species (Cox's Bazar). This might be occurred because natural/wild species was found tangled with marine litter in the shallow coastal waters. Studies reported that the estuaries and coastal waters of the east coast of Bangladesh, northern Bay of Bengal faced serious contamination because of massive discharging of untreated effluent from a large number of factories (e.g., Rani et al., 2021) which might be one of the causes of seaweeds heavy metals contamination. Moreover, tourists are indiscriminately dump waste not only in the beach but also in sea water which was hazardous for marine environment. Most of the plastic or other wastes are non-biodegradable and mixed with the habitat of or attached to the marine algae which act as the vector for micro/nanoplastic transfer in the marine food web ( $\mathrm{Li}$ et al., 2020). In contrast, in Cox's Bazar, seaweed species are cultured in a fixed area with proper management and care where anthropogenic sources of pollution particularly beach waste or plastic pollution are limited. This might be one of the reasons of lower heavy metal contamination in cultured seaweeds than wild species.

This study showed the concentration of heavy metals in seaweeds varied from species to species. This is because some seaweeds show strong attraction to absorb heavy metals, and the level of affinity to absorb heavy metals are significantly reliant on the environmental factors (salinity, temperature and $\mathrm{pH}$ fluctuations, photoperiods, nutrients availability and concentrations, etc. (Besada et al. 2009; Wells et al., 2017). Moreover, seaweeds are able to purposively accumulate minerals in their thalli from the seawater (Azmat et al., 2006) and that is why, seaweeds mineral concentrations are species and place specific. This study showed the maximum concentration of $\mathrm{Pb}$ was recorded in $P$. pavonica $(20.55 \mathrm{mg} / \mathrm{kg}-\mathrm{dw})$ followed by $C$. sinuosa (16.99 mg/kg-dw) (Table 3). But $\mathrm{Pb}$ concentration was not detected in cultured Hypnea sp. and wild Sargassum sp. This study found that the concentration of $\mathrm{Cd}$ was the lowest in all seaweeds and it was varied from $0.98 \mathrm{mg} / \mathrm{kg}$-dw to $3.55 \mathrm{mg} / \mathrm{kg}-\mathrm{dw}$. The peak Cd content was reported in $P$. pavonica $(3.55 \mathrm{mg} / \mathrm{kg}-\mathrm{dw})$ and least was found in cultured Hypnea sp. $(0.98 \mathrm{mg} / \mathrm{kg}-\mathrm{dw})$. The intensity and magnitude of heavy metals concentrations in seaweeds might depend on the level of pollution or the sources of contamination. Rizvi and Shameel (2005) reported the concentration of $\mathrm{Pb}(15.93 \mathrm{mg} / \mathrm{kg}-\mathrm{dw})$ and $\mathrm{Cd}(2.33 \mathrm{mg} / \mathrm{kg}-\mathrm{dw})$ in $C$. sinuosa was nearly in line with the present study.

\section{Variation of mineral and heavy metal concentrations in algal groups}

This study found that mineral concentrations were varied in different seaweed samples when they are grouped as red, green and brown (Figure 1). Results showed that $\mathrm{Ca}$ concentration was the highest in Phaeophyta group (18565 mg/kg-dw) and it was 19 times higher than the value reported in Chlorophyta $(950 \mathrm{mg} / \mathrm{kg}-\mathrm{dw})$ which indicated brown seaweeds are a good source of $\mathrm{Ca}$. In most of the brown seaweeds such as Sargassum sp., H. clathratus, $P$. pavonica, $C$. sinuosa, $P$. fascia and D. ciliolata, the concentration of $\mathrm{Ca}$ was comparatively very high than rest of the studied minerals (Table 3). This is because brown seaweeds demonstrate higher level of disparity in mineral contents depend on various environmental issues such as chemical composition (e.g., concentrations of different metals and their interactions in sea water), physicochemical parameters (e.g., salinity, $\mathrm{pH}$ and photoperiods intensity), growth and metabolic parameters like dilution or changes of metal's concentration because of seaweed growth (Carlson and Erlandsson, 1991; Topcuoğlu et al., 2003; Żbikowski et al., 2006). In contrast, mean concentration of $\mathrm{Fe}, \mathrm{Zn}$ and $\mathrm{Mn}$ were the maximum in Rhodophyta. The mean concentration of Fe (11670 
$\mathrm{mg} / \mathrm{kg}$-dw) in Rhodophyta was almost double than the estimated $\mathrm{Fe}$ concentration in Chlorophyta (5560 $\mathrm{mg} / \mathrm{kg}-\mathrm{dw}$ ). This is because red seaweeds encompass significantly greater concentration of $\mathrm{Fe}$ than that of green and brown seaweeds (Rohani-Ghadikolaei et al., 2012). Among different phyla, mean concentrations of $\mathrm{Zn}$ and $\mathrm{Mn}$ were comparatively very lower than rest of the minerals.

Results showed that heavy metal concentration of $\mathrm{Pb}$ was the highest in Phaeophyta group and it was $11.53 \mathrm{mg} / \mathrm{kg}-\mathrm{dw}$ (Figure 2). $\mathrm{Pb}$ is not a vital component for the human body, thus, extreme level of $\mathrm{Pb}$ intake may harm the circulatory, endocrine, nervous, skeletal, enzymatic and immune structures. Particularly children, pregnant women and elderly persons are sensitive to $\mathrm{Pb}$ exposure that has substantial adverse impacts on intelligence quotients and physical development (Zhang et al., 2012). The concentration of $\mathrm{Cd}$ was the lowest in Rhodophyta, Chlorophyta and Phaeophyta. However, mean $\mathrm{Cd}$ concentration was higher in green seaweed than red and brown seaweeds. Since $\mathrm{Cd}$ is a nonessential element for human health (Revitt et al., 2013), higher level of $\mathrm{Cd}$ ingestion may result in lung damage, renal damage and skeletal changes (Godt et al., 2006; Bernar, 2008).

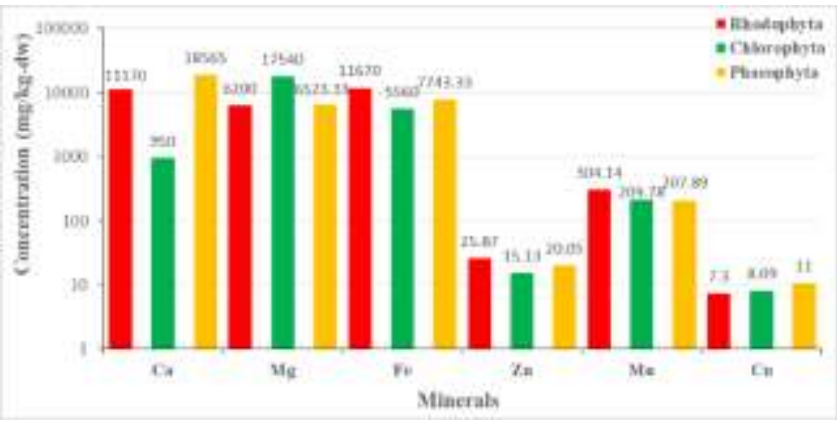

Figure 1: Variation of Mineral Concentrations (mg/kg-dw) in Different Wild Seaweeds Phyla Collected from Southeastern Part of Bangladesh, Northern Bay of Bengal

The mineral composition of seaweeds may be influenced by environmental conditions (Holdt and Kraan, 2011; Rubio et al., 2017; Siahaan et al., 2018), their age, and their capability to absorb inorganic elements from the surroundings due to the presence of polysaccharides-based cell walls. Brown seaweeds have higher absorption rates than green and red seaweeds owing to the existence of alginate, alginic acid salts and alginic acid (Siahaan et al., 2018). These polysaccharides have an affinity with $\mathrm{Ca}$ and
$\mathrm{Mg}$ salts. However, seaweeds accumulate not only desirable minerals but also undesirable metals from the surrounding environment to hazardous levels and migrate to the human body through the diet, resulting in negative health effects such as allergies, hyperpigmentation, and cancer caused (Holdt and Kraan, 2011; Rubio et al., 2017; Siahaan et al., 2018).

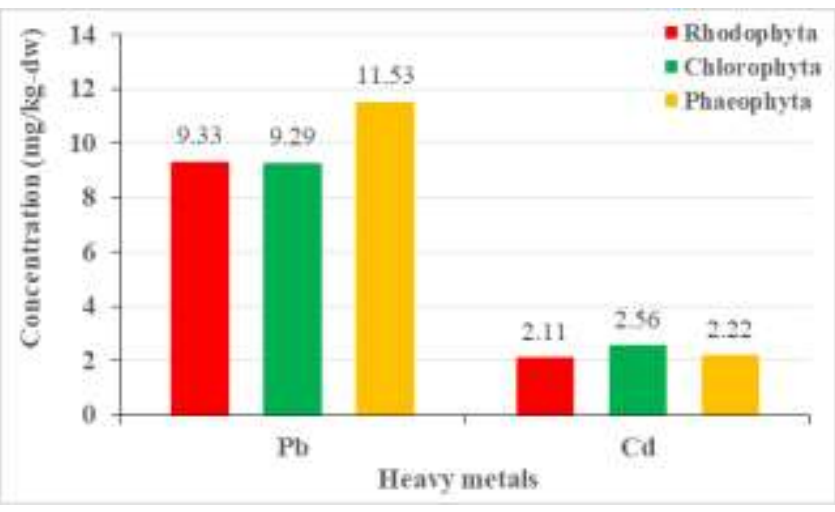

Figure 2: Variation of Heavy Metals Concentrations (mg/kg-dw) in Different Wild Seaweeds Phyla Collected from South-eastern part of Bangladesh, Northern Bay of Bengal

Seaweeds encompass greater amount of minerals than terrestrial plants and vegetations (Rupérez, 2002) and in some cases, the content would be as high as 40\% (Kumar et al., 2011; Nwosu et al., 2011). This is because seaweeds absorb most of the minerals that are rich in macro- and trace elements from the seawater. The minerals in seaweeds are very essential for health maintenance. Globally around two billion people are suffered from Fe deficiency and majority of them are child and pregnant women (WHO, 2015). Findings of the current study suggested that seaweeds could be consumed as a potential source of Fe to fight against iron deficiency. Because $\mathrm{Fe}$ acts as an element of numerous metabolic functions such as oxygen carriage, electron transfer, and oxidase activities, while $\mathrm{Mn}$ is a cofactor of several metalloenzymes (e.g., superoxide dismutase, arginase, etc.) which is linked to amino acid, carbohydrate and lipid metabolism (Mišurcová et al., 2011). Similarly, Cu and $\mathrm{Zn}$ are fundamental elements of many enzymes that are connected with neurotransmitter synthesis, energy metabolism and collagen/elastin cross-linking (Osredkar and Sustar, 2011). Thus, seaweeds could be consumed as a functional food to fulfil the daily demand of recommended indispensable minerals and trace nutrients intake for the poor coastal people of Bangladesh. 
This study found that the concentrations of minerals in all seaweeds showed moderately bigger values than potentially toxic metals (Table 3). However, heavy/toxic metals do not have beneficial effects in humans, in contrast, they have adverse effects on the body by impairing or over-stimulating an important chemical process (Balali-Mood et al., 2021). In Bangladesh, seaweeds consumption as a food is not widely accepted by the mass population. However, in recent years, its consumption is gradually increasing as public awareness is rising. At the same time, public health concern to consume seaweeds gets mass attention since seaweeds can absorb significant concentrations of heavy metals. As a result, a standard reference or maximum permissible level (MPL) is need to set to consume seaweeds. However, in Bangladesh, there has no specific regulation or standard reference on MPL of heavy metal contamination in seaweeds. France, the first European country, formulated a precise guideline regarding the consumption of seaweeds and French legislation has recommended a MPL for Cd in dehydrated seaweed of $0.5 \mathrm{mg} / \mathrm{kg}-\mathrm{dw}$ (Besada et al., 2009). Bangladesh government can set a maximum acceptable limit of heavy metals contaminations in seaweeds for the safe consumption of the people.

\section{CONCLUSIONS}

This study estimated the concentrations of several minerals such as $\mathrm{Ca}, \mathrm{Mg}, \mathrm{Fe}, \mathrm{Zn}, \mathrm{Mn}$ and $\mathrm{Cu}$, and heavy metals $(\mathrm{Pb}$ and $\mathrm{Cd})$ from cultured and wild seaweeds species collected from coastal waters of Cox's Bazar and St. Martin's Island of Bangladesh, northern Bay of Bengal. Results showed that seaweeds are rich in valuable minerals that are very obligatory for the health maintenance. Seaweeds can fulfil the nutritional requirement of daily intake of minerals for the mass population at a low cost. Thus, seaweeds can be considered as a functional food for the coastal people particularly for the coastal vulnerable poor, women, elderly and tribal communities.

This study showed seaweeds are contaminated by few heavy metals such as $\mathrm{Pb}$ and $\mathrm{Cd}$ and this study is the first of its kind that provides evidence on heavy metal contamination in seaweeds from coastal waters of Bangladesh. The evidence of heavy metal contamination in seaweeds raises public health concerns to consume the seaweeds. However, the level of contamination in wild and cultured seaweeds is not same. Cultured seaweeds are comparatively less contaminated by heavy metals than the wild seaweeds which indicated careful management and less anthropogenic sources of pollution might influence the contamination level. This study suggests, the authority can establish a guideline or set a regulation for the maximum acceptable limit of heavy metals in seaweeds for safe consumption in future. Further studies can be conducted extensively to identify other minerals and potentially toxic heavy metals in seaweeds for health safety management.

\section{Acknowledgements}

The authors would like to thank Institute of Nutrition and Food Science (INFS), University of Dhaka for the necessary permission to carry out sample preparation in their laboratory. The authors are greatly indebted to Bangladesh Council of Scientific and Industrial Research (BCSIR) for carrying out microwave digestions and Centre for Advanced Research in Sciences (CARS), University of Dhaka for helping with chemical analyses. The authors also would like to acknowledge Ministry of Science and Technology, Government of the People's Republic of Bangladesh for the financial support.

\section{REFERENCES}

Astorga-España, M. S., Galdón, B. R., Rodríguez, E. R., and Romero, C. D. (2015). Mineral and trace element concentrations in seaweeds from the sub-Antarctic ecoregion of Magallanes (Chile). Journal of Food Composition and Analysis, 39: 69-76.

Azmat, R., Hayat, A., Khanum, T., Talat, R., and Uddin, F. (2006). The inhabitation of bean plant metabolism by $\mathrm{Cd}$ metal and Atrazine III: effects of seaweed Codium Iyengaria on metal, herbicide toxicity and rhizosphere of the soil. Biotechnology, 5(1): 85-89.

Balali-Mood, M., Naseri, K., Tahergorabi, Z., Khazdair, M. R., \& Sadeghi, M. (2021). Toxic mechanisms of five heavy metals: mercury, lead, chromium, cadmium, and arsenic. Frontiers in Pharmacology, 12: 643972.

Bernard, A. (2008). Cadmium \& its adverse effects on human health. Indian Journal of Medical Research, 128(4): 557.

Besada, V., Andrade, J. M., Schultze, F. and González, J. J. (2009). Heavy metals in edible seaweeds commercialised for human consumption. Journal of Marine Systems, 75(1-2): 305-313.

Carlson, L. and Erlandsson, B. (1991). Effects of salinity on the uptake of radionuclides by Fucus vesiculosus 
L. Journal of Environmental Radioactivity, 13(4): 309322.

Chen, Q., Pan, X. D., Huang, B. F. and Han, J. L. (2018). Distribution of metals and metalloids in dried seaweeds and health risk to population in southeastern China. Scientific Reports, 8(1): 1-7.

Feed the Future. (2021). Success through seaweed in Bangladesh. https://www.feedthefuture.gov/article/success-throughseaweed-in-bangladesh/ (accessed: 1 October 2021)

FSSAI. (2015). Manual of methods of analysis of foods metals. Lab manual 9. Food Safety and Standards Authority of India, Ministry of Health and Family Welfare, New Delhi, India. pp. 3-82.

Godt, J., Scheidig, F., Grosse-Siestrup, C., Esche, V., Brandenburg, P., Reich, A., \& Groneberg, D. A. (2006). The toxicity of cadmium and resulting hazards for human health. Journal of Occupational Medicine and Toxicology, 1(1): 1-6.

Holdt, S. L. and Kraan, S. (2011). Bioactive compounds in seaweed: functional food applications and legislation. Journal of Applied Phycology, 23(3): 543597.

Hossain, M. S., Sharifuzzaman, S. M., Nobi, M. N., Chowdhury, M. S. N., Sarker, S., Alamgir, M., Uddin, S. A., Chowdhury, S. R., Rahman, M. M., Rahman, M. S., \& Chowdhury, S. (2021). Seaweeds farming for sustainable development goals and blue economy in Bangladesh. Marine Policy, 128, 104469.

Khan, M. S. K., Hoq, M. E., Haque, M. A., Islam, M. M. and Hoque, M. M. (2016). Nutritional evaluation of some seaweeds from the Bay of Bengal in contrast to inland fishes of Bangladesh. Journal of Environmental Science, Toxicology and Food Technology, 10(11), 5965.

Khandaker, M. U., Chijioke, N. O., Heffny, N. A. B., Bradley, D. A., Alsubaie, A., Sulieman, A., Faruque, M. R. I., Sayyed, M. I., \& Al-Mugren, K. S. (2021). Elevated concentrations of metal (loids) in seaweed and the concomitant exposure to humans. Foods, 10(2): 381 .

Kumar, C. S., Ganesan, P., Suresh, P. V., \& Bhaskar, N. (2008). Seaweeds as a source of nutritionally beneficial compounds-a review. Journal of Food Science and Technology, 45(1): 1-13.

Kumar, M., Kumari, P., Trivedi, N., Shukla, M. K., Gupta, V., Reddy, C. R. K., \& Jha, B. (2011). Minerals, PUFAs and antioxidant properties of some tropical seaweeds from Saurashtra coast of India. Journal of Applied Phycology, 23(5): 797-810.
Li, Q., Feng, Z., Zhang, T., Ma, C., \& Shi, H. (2020). Microplastics in the commercial seaweed nori. Journal of hazardous materials, 388: 122060.

Mišurcová, L., Machů, L., \& Orsavová, J. (2011). Seaweed minerals as nutraceuticals. Advances in Food and Nutrition Research, 64, 371-390.

Muñoz, I. L. and Díaz, N. F. (2020). Minerals in edible seaweed: health benefits and food safety issues. Critical Reviews in Food Science and Nutrition, 1-16.

Nwosu, F., Morris, J., Lund, V. A., Stewart, D., Ross, H. A., \& McDougall, G. J. (2011). Anti-proliferative and potential anti-diabetic effects of phenolic-rich extracts from edible marine algae. Food Chemistry, 126(3): 1006-1012.

Osredkar, J., \& Sustar, N. (2011). Copper and zinc, biological role and significance of copper/zinc imbalance. J Clinical Toxicology, 3(2161): 0495.

Revitt, D. M., Lundy, L., Eriksson, E., \& Viavattene, C. (2013). Comparison of pollutant emission control strategies for cadmium and mercury in urban water systems using substance flow analysis. Journal of Environmental Management, 116: 172-180.

Rizvi, M. A., \& Shameel, M. (2005). Pharmaceutical biology of seaweeds from the Karachi coast of Pakistan. Pharmaceutical Biology, 43(2): 97-107.

Rohani-Ghadikolaei, K., Abdulalian, E., \& Ng, W. K. (2012). Evaluation of the proximate, fatty acid and mineral composition of representative green, brown and red seaweeds from the Persian Gulf of Iran as potential food and feed resources. Journal of Food Science and Technology, 49(6): 774-780.

Rubio, C., Napoleone, G., Luis-González, G., Gutiérrez, A. J., González-Weller, D., Hardisson, A., \& Revert, C. (2017). Metals in edible seaweed. Chemosphere, 173, 572-579.

Rupérez, P. (2002). Mineral content of edible marine seaweeds. Food Chemistry, 79(1): 23-26.

Siahaan, E. A., Pangestuti, R., \& Kim, S. K. (2018). Seaweeds: valuable ingredients for the pharmaceutical industries. In: Rampelotto, P. H., \& Trincone, A. (eds) Grand challenges in marine biotechnology. Springer: Cham. pp. 49-95.

Tabarsa, M., Rezaei, M., Ramezanpour, Z., Robert Waaland, J. and Rabiei, R. (2012). Fatty acids, amino acids, mineral contents, and proximate composition of some brown seaweeds. Journal of Phycology, 48(2): 285-292. 
Topcuoğlu, S., Güven, K. C., Balkıs, N., \& Kırbaşoğlu, Ç. (2003). Heavy metal monitoring of marine algae from the Turkish Coast of the Black Sea, 19982000. Chemosphere, 52(10):1683-1688.

Uddin, S. A. (2019). Seaweeds of Bangladesh. Institute of Marine Sciences, University of Chittagong, Bangladesh. 174p.

USEPA. (1995). QA/QC Guidance for Sampling and Analysis of Sediments, Water, and Tissues for Dredged Material Evaluations: Chemical Evaluations (No. EPA823-B-95-001). Washington, DC: Office of Water, United States Environmental Protection Agency.

Wells, M. L., Potin, P., Craigie, J. S., Raven, J. A., Merchant, S. S., Helliwell, K. E., Smith, A. G., Camire, M. E., \& Brawley, S. H. (2017). Algae as nutritional and functional food sources: revisiting our understanding. Journal of Applied Phycology, 29(2): 949-982.

World Bank. (2018). Bangladesh: reducing poverty and sharing prosperity. Washington, DC: The World Bank.
Yoganandham, S. T., Raguraman, V., Muniswamy, G., Sathyamoorthy, G., Renuka, R. R., Chidambaram, J., Rajendran, T., Chandrasekaran, K., \& Ravindranath, R. R. S. (2019). Mineral and trace metal concentrations in seaweeds by microwave-assisted digestion method followed by quadrupole inductively coupled plasma mass spectrometry. Biological Trace Element Research, 187(2): 579-585.

Żbikowski, R., Szefer, P. and Latała, A. (2006). Distribution and relationships between selected chemical elements in green alga Enteromorpha sp. from the southern Baltic. Environmental Pollution, 143(3): 435-448.

Zhang, X., Yang, L., Li, Y., Li, H., Wang, W., and Ye, B. (2012). Impacts of lead/zinc mining and smelting on the environment and human health in China. Environmental Monitoring and Assessment, 184(4): 2261-2273. 
